\title{
The Using of Implicature in Poem by William Henry Davies
}

\section{| Muhammad Natsir ${ }^{1}$ | Bahagia Saragih ${ }^{2}$ | Rafika Dewi Nasution ${ }^{3}$ | | Christine Helena Natalia ${ }^{4}$ |}

\author{
1,2,3,4 English and Literature \\ Department, Faculty of \\ Languages and Arts, \\ Universitas Negeri Medan, \\ Indonesia \\ 1natsirfbs@unimed.ac.id \\ ²yabucks123@gmail.com \\ 3fikabornast@gmail.com \\ ${ }^{4}$ christinehelena@unimed.ac.id
}

\begin{abstract}
This paper aims to compare and analyze the five poems that written by five different poets to find the implicature in all that poems and try to find the literal meaning behind every poem that the writer took as their data. And for this research, the writer comes with the qualitative study with the descriptive method to analyze this research, where with this method the writer attempt to describe and interpret the object of the research because the data has presented descriptively. The analysis of this research has been done with read the poem thoroughly to find the implicature from the poem then describing how the types represented in each poem, and explaining the significant differences among the five poems.
\end{abstract}

KEYWORDS

implicature; poem; William Henry Davies

\section{INTRODUCTION}

An implicature is something the speaker recommends or suggests with an expression, indeed in spite of the fact that it isn't truly communicated. Implicatures can help in communicating more productively than by expressly saying everything we need to communicate.

Generally, people used direct utterances, nevertheless sometimes they used implicature strategies to make hearers gets responses like what the speaker wanted. Implicature was a process of interpretation based on context of situation, whether mean that it was what speaker implied, suggested, or mean in a different way from what they said. Gazdar (1978) characterized that implicature as a suggestion that was suggested by the articulation of a sentence in a setting, indeed in spite of the fact that that suggestion was not a portion of nor entailment of what was really said. There were conventional implicature and conversational implicature.

Agreeing to Thomas (1995) there were two sorts of implicatures. They were Conversational Implicature and Customary Implicature. Both of them passed on the meaning of the expression. Thomas clarified that they varied in that within the case of customary implicature, the same implicature was continuously passed on, regardless of setting, though within the case of conversational implicature that was inferred shifts concurring to the setting of expression.

Verse may be a sort of composing, or inventive composing, that endeavors to blend a reader's imaginative capacity or sentiments. The author does this by carefully choosing and organizing lingo for its meaning, sound, and cadence. In verse, words are strung together to create sounds, pictures, and concepts that may well be as well complex or unique to portray straightforwardly. Some poems, such as nursery rhymes, are simple and humorous. 


\section{LITERATURE REVIEW}

\section{Previous Study}

This research is based on preview research in "Grice's Conversational Implicature: A Pragmatics Examination of Chosen Lyrics of Audre Lorde"'s diary. The number of works completed by researchers on the consider and elucidation of Audre Lorde's verse, particularly through the focal point of scholarly and basic examination. Be that as it may, The lyrics of Lorde have not been studied practically. A part may have been composed approximately Lorde's verse, but there's completely no prove of a pragmatics consider of her work. Lorde is the creator of numerous lyrics that have been examined in different hypothetical measurements, However, none have been completed with regard to their pragmatics suggestions. The issue which this investigate recognizes, hence, is that Lorde's sonnets, particularly the ones beneath the show think about, have not been examined and deciphered utilizing Grice's hypothesis of Conversational Implicature (Agreeable Guideline) which is comprised the four proverbs: the adages of Amount, Quality, Way and Connection. This ponder looks for to determine the extent to which these sayings can be connected to the perusing of the chosen lyrics of Lorde. It moreover looks for to discover the extent to which Lorde's selected sonnets abuse or follow to these proverbs. The think about has found that Audre Lorde in a few of her lyrics, damages Both the maxims and what follows from them are mentioned in the same sentence.

\section{Theory of Pragmatics}

A pragmatics explanation of writing demonstrates that in academic communication, we do not as it were have a scholarly content, but moreover the emotive impacts of scholarly elucidation which incorporate desires, wishes, wants, likings and sentiments of the creator. Pragmatics, as we know it, is that level of etymological examination which ponders meaning in setting. Yule (as cited by Osisanwo, 2003, p. 55), attests that pragmatics is "concerned with the ponder of meaning as communicated by a speaker (or author) and translated by the audience" When someone speaks around pragmatics, one is essentially speaking approximately meaning past the phonetic information, to put it another way, pragmatics looks after the inferred meaning of an expression which might as it were be gathered inside the setting.

The pragmatics of scholarly communication bargains with the sorts of issues, such as the various types of activities fulfilled by the generation of the scholarly content (i.e. the sonnet), the suitable conditions of those activities, and the connections in between the activities and their settings (Van Dijk, 1981, p. 13-16). A content actuates its mediator to develop an picture, or perhaps a group of elective pictures. Whereas the picture development and picture amendment are taking place, the translator likewise tries to figure out what the maker of the content is carrying out what the nature of the communication requires circumstance is all around. In any case, fruitful translation, at that point, the peruser has got to create a list of deductions from which the relevant suggestion can be inferred. Understanding and translating verse requires understanding and increasing in value of authentic and social conditions and ideological variables beneath which the journalists discover themselves. Subsequently, the pragmatics affect of the lyric grasps the entirety of the sonnet together with its passionate, mental and inventive request (Indede, 2009, p. 107).

\section{Theory of Implicature}

Parker, Wijana $(1962 ; 1996)$ said that The Implicature could be a suggestion that's as often as possible covered up behind the discourse created and isn't a coordinate portion of that 
discourse. That can conclude that implicature is what is said different is different from what is implied. This is same with opinion of Hence, Wright (1975: 379) said that what is said different ffrom what is meant is not what is said. The issue of conversational implicature, agreeing to Levinson, is the foremost vital one within the ponder in terms of pragmatics. It occurs since the issue of conversational implicature is specifically related to commonsense utilization of dialect, both verbal and non-verbal (Edmondson, 1981: 38). Agreeing to Brown and Yule (1983: 27), implicature is the components exterior of the content. In case it is returned to the starting concept, it can be caught on that the relationship between the two relational words - discourse and the suggestion isn't an supreme result (Parker, 1986: 21).

\section{Types of Implicature}

Implicature comprises of two sorts: customary implicature and conversational implicature (Grice, 1975: 44).

\section{Conventional Implicature}

Customary implicature is the suggestion which is common and routine. In common, everybody has known and caught on the meaning or suggestions of a case. Understanding the suggestions expectedly assumes the audience or per user to have encounter and common information. It is critical to note the suggestion of "beat" and "Italy". The primary lexem implies overcoming, not beating like what is implied by employing a paddle or wood, and lexem "Italy" is as one of the football group competing within the football competition, not the title of a state government.

Ordinary implicature isn't much considered by specialists of pragmatics because it isn't so interesting (Brown and Yule, 1983: 31). Usually due to the suggestions contained tend to be firm and don't have much meaning. Sort of implicature which is considered more appealing and exceptionally imperative within the consider of down to earth is conversational implicature. The think about of conversational implicature will offer assistance in opening and expanding the advancement of down to business.

\section{Conversational Implicature}

Conversational implicature shows up in discussion act. In this manner, the nature of implicature is brief and non-conventional straightforwardly with articulation talked (Levinson, 1991: 117). According to Grice (1975: 45) there's a set of presumptions that cover and direct the exercises of the discussion as a discourse act. Concurring to Grice's investigation, a set of suspicions that direct somebody in discussion is agreeable principles.

\section{RESEARCH METHODS}

Investigate strategy could be a brief layout of the foremost critical thinks about that have been conducted so distant displayed in a chronological arrange. Investigate strategy ought to too incorporate a brief dialog of major hypotheses and models related to the inquire about issue. When composing inquire about technique, you too have to be illustrate how your investigate relates to what has been done so distant in this inquire about zone.

Kothari (2004) expressed that, investigate technique may be a strategy to logically explain the investigate issue. It may be depicted as a science of examination how investigate is done systematically. In it we examine the different stages that are for the most part actualized by a scholar in examining his issue of investigate in conjunction with the reason behind them. Furthermore, " Investigate strategies are the tools and techniques used to conduct research. 
But in the other perspective by John W. Cresswell (2009:3) research methodology is plans and the strategies for inquire about to nitty gritty strategies of information collection and examination. So within the other words, investigate strategy is the specific strategies or strategies used to distinguish, choose, prepare, and analyze data around a theme. Instep, a strategy offers the speculative supporting for understanding which technique, set of techniques, or best sharpens can be associated to a specific case, for case, to calculate a specific result.

In the research methodology there are two kinds of method that we can use, which is Qualitative research and Quantitative research. Subjective inquire about is multi method in nature, with an interpretive, naturalistic approach to its subject matter at its center. Or in without further, Subjective Investigate is an experimental investigation in which the information is not contained within a numerical framework.

Quantitative research collects data in a numerical format that can be organized into categories, ranked, or measured in units of estimation. This sort of information can be utilized to develop charts and tables of crude information. Quantitative investigators emphasize the significance of setting up common rules of behavior and considering diverse settings/contexts.

In this investigate, the author utilized plan of descriptive method which may be a strategy of investigate that endeavor to portray and decipher the objects in understanding with reality. The clear strategy is actualized since the information investigation is displayed expressively and the researchers used 5 poem by some poet.

Additionally, Endraswara (2011) gives the imperative highlights of subjective investigate in examining the writing, such as the analyst is the key of instrument that peruses the writing thrifty, the inquire about is done distinctly which explained within the shape of words or pictures than numbers, and the method is more need than result, since writing builds up elucidations.

In addition, (Ary, 2010:421) gave a suggestion to all the researchers to chose the subject by applying certain criteria. "Qualitative ponders more ordinarily utilize nonrandom or purposive choice strategies based on specific criteria". It implied that the analyst doesn't take a subject arbitrarily to urge fitting information in this investigate.

And now for this work, we divide this method in three section, first one is we going to explain about the object of this research and the second one we will explain about the instrument of this research, last will be the technique of collecting data.

\section{Object of Research}

In this research, the writer use five poem that published in English and that poetry will be analyzed by the writer to find the implicature behind every words in that poetry.

\section{The Instrument of Research}

The writer doing their analyze on five poems by some concerning, which is:

1. How is the poet using the implicature on their poems ?

2. Is there any implicature in them ?

3. What is the implicature behind their poems ?

4. Identifying the types of implicature used in their poems

5. Describing how the types represented in each text

6. Explaining the significance differences among them 


\section{The Technique of Collecting Data}

This data using qualitative method, which is the data are focused on certain practices or behaviors, and then showing how these behaviors or practices can be grouped to lead to the observed results. This research is more subjective, and requires careful interpretation of the behaviors.

We try to analyze how is the implicature used in poems and what kind of implicature is that they use. We focused on how the poet using the implicature on their poems and what is the meaning of that implied words on that poems and identifying the types of implicature used in each poem, then classifying them to indicate the total number of types occurred and the most dominant type. Also, we describing how the types represented in each poem, and explaining the significant differences among the five poems.

\section{RESULTS AND DISCUSSION}

In this research, we going to comparing and analyzing the five poems in English. There are, "The Villain" by William Henry Davies and then "Mark" by Linda Pastan, the third one is "Is The Moon Tired" by Christina Georgina Rosetti and the fourth one is "Barbie Doll' by Maggie Pierce and the last poem entitled "Mirror" by Sylvia Plath.

\section{The Villain (William Henry Davies)}

While joy gave clouds the light of stars,
That beamed wher'er they looked;
And calves and lambs had tottering knees,
Excited, while they sucked;
While every bird enjoyed his song,
Without one thought of harm and wrong -
I turned my head and saw the wind,
Not far from where I stood
Dragging the corn by hor golden hair,
Into the dark and lonely wood.

In this poem, we can see implicature in it because the poet using some figurative language and write them metaphorically. And when we read this poem, the question that rise in our mind is who is the villain? Because in there, the poet did not tell who is the villain. From the line 1 and the line 2, we can see they have implicature in it because they implicate about the situation where is the beautiful night sky with full of stars who are beaming and the word of "joy" in there implicate the weather who is want to play with them with give them the gale or wind.

In the line 4 until line 5, we can implicate them as the wind who blown strongly and after that strong wind come all the birds fly away, because from the word "while every bird enjoyed his song" implicate that the sound of flutter of bird wings when they fly as their song. And from these explanation, line 4 and 5 has correlation with line 1 and 2 because as the writer told before, "Joy" word means that the night sky who wants to play because she feels happy and the way that she wants to play with us with playing by the wind that implied from the line 4 and 5.

In the line 9 and 10, we can see the implicature in it because, those line will be implied all the corn that planted in the farm has been lost and fallen down to the ground. So overall, after we analyze this poem line by line, we can find who is the villain here, the villain in this poem implied to the wind because due to the arrival of strong winds ruin their farm. 
The language in this poem starts with the story in the past. There is no a lyrics that far with the title. Even the title that the poet uses is the pronoun to make interest the reader about the poem and to implicate the winds. And from this poem, we can see that the poet using the conversational type of implicature because, in this poem she spoken about the winds who comes away and make a joke with the speaker by throwing out the corn to the ground and messing up all the farm and also the main point is because in this poem the poet using the metaphor language and metaphor language is one of the characters of conversational language.

\section{Mark (Linda Pastan)}

\begin{tabular}{|c|}
\hline My husband gives me an A \\
for last night's supper, \\
an incomplete for my ironing, \\
a B plus in bed. \\
My son says I am average, \\
an average mother, but if \\
I put my mind to it \\
I could improve. \\
My daughter believes \\
in Pass/Fail and tells me \\
I pass. Wait 'til they learn \\
I'm dropping out
\end{tabular}

In this poem, as we can see the way of Linda write her poem with literal meaning because in her poem she just confessed what her feeling about the score that she got from her family. Because this poem using literal meaning, doesn't mean this poem doesn't have implicature because based on the definition of implicature may be a specialized term, which alludes to what is proposed in an articulation, indeed in spite of the fact that not one or the other communicated nor entirely suggested or in shortly we can say implicature is something that usually is not conveyed directly, but rather implied.

This poem implied there are a housewife who get supervised and get score by her husband and her kids when she does the chores of their house and she want to do revenge for them when they get learned how to do all the chores.

The type that the poet used on this poem is the customary implicature, an implicature which is portion of a lexical thing or meaning that's agreed upon expression, instead of inferred from the standards of dialect utilize, and not portion of the conditions for thing truth or expression. Means that in this poem as we can see that the poet deliver that poem with the subject convey her feeling than with the language use.

\section{Is the Moon Tired (Christina Georgina Rosetti)}

\begin{tabular}{|} 
Is the moon Tired? She look so pale \\
Within her misty veil \\
She scales the sky from east to west, \\
And takes no rest \\
Before the coming of the night \\
The moon shows papery white; \\
Before the dawning of the day \\
She fades away
\end{tabular}


In this poem, the poet using the figurative meaning which means metaphorical language, because in that poem the poet makes the object or the moon seems act like a human. This poem as same as the first poem, this poem using the conversational implicature because in this poem the poet using the lexical item or the using of language than the feeling and the important one is because this poem using metaphorical language.

This poem absolutely have an implicature. This poem implied about how the shape of the moon in the sky and signs of the moon appear and set the moon as a sign of changing time.

\section{Barbie Doll (Maggie Pierce)}

This girlchild was born as usual
and presented dolls that did pee-pee
and miniature GE stoves and irons
and wee lipsticks the color of cherry candy.
Then in the magic of puberty, a classmate said:
You have a great big nose and fat legs.
She was healthy, tested intelligent,
possessed strong arms and back,
abundant sexual drive and manual dexterity.
She went to and fro apologizing.
Everyone saw a fat nose on thick legs.
She was advised to play coy,
exhorted to come on hearty,
exercise, diet, smile and wheedle.
Her good nature wore out
like a fan belt.
So she cut off her nose and her legs
and offered them up.
In the casket displayed on satin she lay
with the undertaker's cosmetics painted on,
a turned-up putty nose,
dressed in a pink and white nightie.
Doesn't she look pretty? everyone said.
Consummation at last.
To every woman a happy ending

In this poem, there are implicature in it because this poem has a meaning that we can implied. This poem implied about there a teenage girl who looks fat and doesn't have a nice figure like the other girl and she got bullied with her classmate. Her school life so hard just because she doesn't look like what the other wants and she always asked to do diet and because of that she doesn't feel happy with her life and she can not enjoy her life and spend her school life happily until she decide to do a plastic surgery and do the transformation of her body, even though she feel pain because of that surgery she does not care because the one thing that keeps in her mind is she doesn't want to get bullied ever and she wants to be happy. And in the end of the day, when she comes with her new figure, everybody was amazed with her beauty and she is happy now.

The poem entitle barbie doll has come with the conventional type, because this poem has the same characteristic with the second poem before which is write the poem with concerning the feeling than the lexical item. 


\section{Mirror (Sylvia Plath)}

\begin{tabular}{|} 
I am silver and exact. I have no preconceptions. \\
What ever you see I swallow immediately \\
Just as it is, unmisted by love or dislike. \\
I am not cruel, only truthful--- \\
The eye of a little god, four-cornered. \\
Most of the time I meditate on the opposite wall. \\
It is pink, with speckles. I have looked at it so long \\
I think it is a part of my heart. But it flickers. \\
Faces and darkness separate us over and over. \\
Now I am a lake. A woman bends over me, \\
Searching my reaches for what she really is. \\
Then she turns to those liars, the candles or the moon. \\
I see her back, and reflect it faithfully. \\
She rewards me with tears and an agitation of hands. \\
I am important to her. She comes and goes. \\
Each morning it is her face that replaces the darkness. \\
In she has drowned a young girl, and in me an old woman \\
Rises toward her day after day, like a terrible fish.
\end{tabular}

The implication of this poem is the function of mirror and the figures of mirror itself. This poem tells how the mirror works and tells about all the girls who really like mirror and always spend their time to mirroring their-self to see how their real appearance without any liars and how the mirror do our reflection and showed the real of us.

This poem using the conversational type of implicature with the reason is this poem comes with metaphorical language that didn't show any feeling by the subject and concerning about the using of language, which means that they are the characteristic of conversational type and this poem has the same type with the first and third poem before.

\section{CONCLUSION}

Implicature was a process of interpretation based on context of situation, whether mean that it was what speaker implied, suggested, or mean in a different way from what they said. Thomas clarified that they varied in that within the case of customary implicature, the same implicature was continuously passed on, regardless of setting, while within the case of conversational implicature that was suggested changes agreeing to the setting of articulation. 55), attests that pragmatics is "concerned with the consider meaning passed on by a speaker (or writer) and interpreted by the group of onlookers." When one talks around pragmatics, One is simply speaking. around meaning past the etymological information, that's to say, that pragmatics looks after the suggested the significance of an articulation which seem as it were be induced inside the setting.

We focused on how the poet using the implicature on their poems and what is the meaning of that implied words on that poems and identifying the types of implicature used in each poem, then classifying them to indicate the total number of types occurred and the most dominant type.

This poem using the conversational type of implicature with the reason is this poem comes with metaphorical language that didn't show any feeling by the subject and concerning about the using of language, which means that they are the characteristic of conversational type and this poem has the same type with the first and third poem before. 


\section{REFERENCES}

Florencia, Erlissa. (2014). The Analysis of Conversational Implicature on Tv One's KABAR BANG ONE Animated Editorial Cartoons. Department of Language and Literary Studies. University of Brawijaya. Malang. Jawa Timur. Indonesia.

Igwedibia, Adaoma. (2017). Grice's Conversational Implicature : A Pragmatics Analysis of Selected Poem of Audre Lorde. Department of English and Literary Studies. University of Nigeria, Nsukka, Enugu State. Nigeria.

Lubis, Indah Sari. (2015). Conversational Implicature of Indonesia Lawyers Club Program on Tv One. Fakultas Ilmu Budaya Universitas Mulawarman. Samarinda. Kalimantan Timur. Indonesia.

Michael, Angelina Subrayan. Muthusamy, Chittra. (2015). Conversational Implicature and Cooperativeness in D.H. Lawrence's Sons and Lovers. Academy of Language Studies. University Teknologi MARA. Malaysia.

Xin, Li. Fang, Guo. (2017). An Analysis of Conversational Implicature in Nirvana in Fire From the Perspective of Cooperative Principle. School of Foreign Language. North China Electric Power University. China. 